\title{
CHANGES OF ${ }^{14} \mathrm{C}$ CONCENTRATION IN MODERN TREES FROM UPPER SILESIA REGION, POLAND
}

\author{
Andrzej Z Rakowski ${ }^{1}$ - Sławomira Pawełczyk • Anna Pazdur \\ Silesian University of Technology, Institute of Physics, Radiocarbon Laboratory, ul. Krzywoustego 2, 44-100 Gliwice, Poland
}

\begin{abstract}
Radiocarbon concentration measurements in tree rings from Upper Silesia indicate significantly lower ${ }^{14} \mathrm{C}$ concentration as compared to the concentrations occurring in "clean air" areas. This phenomenon is known as the Suess effect and is caused by contamination with inactive carbon that originates from fossil fuels combustion. This effect is observed in large urban and industrial areas. Samples for the measurements presented in the paper were collected in some of the largest cities in Upper Silesia: Gliwice, Ruda Śląska, and Chorzów. The samples were annual tree rings (Populus nigra, Pinus silvestris) covering years 1965-1992 and the atmospheric $\mathrm{CO}_{2}$ collected weekly between December 1994 and December 1995.
\end{abstract}

\section{INTRODUCTION}

Increase of mining and combustion of fossil fuels like coal, petroleum, natural gas, etc. in industrial areas caused emission of $\mathrm{CO}_{2}$ to the atmosphere and changes of carbon isotopic composition in the atmosphere and other carbon reservoirs.

First investigations of contemporary tree samples (Suess 1955) proved that their radiocarbon activity was lower than in samples from the middle of the 19th century. These measurements allowed evaluation of changes of ${ }^{14} \mathrm{C}$ concentration in the modern biosphere caused by industrial activity. The Suess effect has a global character that is the consequence air masses mixing in the atmosphere and exchange of carbon between the northern and southern hemispheres. The increase of ${ }^{14} \mathrm{C}$ concentration in the atmosphere as a result of nuclear weapon tests in the stratosphere and on the earth's surface, made it impossible to determine the Suess effect directly from measurements of the concentration in the atmosphere and biosphere (Nydal and Lövseth 1983). This determination is only possible when one assumes a mathematical model describing carbon exchange between reservoirs (Oeschger et al. 1975; Siegenthaler and Oeschger 1978). The cause of the local Suess effect is large concentration of sources emitting inactive $\mathrm{CO}_{2}$ in regions that due to climatic conditions and site profile reveal difficulties in mixing and exchange of air mass. Mainly, heavily industrialized areas are subject to such distortion.

\section{STUDY AREA}

Upper Silesia Region (GOP) is a region in the basins of Upper Wisła and Odra, southern Poland (Figure 1). This is the most industrialized area in Poland and its main natural resources are coal deposits. Development of other industrial branches in this area is bound with chemical processing of coal and development of heavy industry utilizing coal as the main source of energy. There are numerous sources of pollution in the area of the Silesia agglomeration, which spreads over 1230 $\mathrm{km}^{2}$. The main gas pollutions are $\mathrm{CO}_{2}, \mathrm{CO}, \mathrm{SO}_{2}$, hydrogen sulfide, and ammonia.

The spatial distribution of the air pollution is diversified. The largest concentration of pollution in GOP was noted in Zabrze, Ruda Śląska, Bytom, Chorzów, and Gliwice. Due to domination of southwest winds, the pollution partly comes from Zagłębie Ostrawsko-Karwińskie in the northern Czech Republic. Towns of Upper Silesia region form a specific urban and industrial area between Mysłowice in the east and Gliwice in the west. Samples were collected within the city boundaries of Ruda Ślaska and Chorzów, but the distances between the sampled locations were not larger than 5 $\mathrm{km}$. Therefore, they can be considered as one site- the center of Upper Silesia industrial area. Sam-

${ }^{1}$ Corresponding author. Email: rakowski@zeus.posl.gliwice.pl.

(C) 2001 by the Arizona Board of Regents on behalf of the University of Arizona RADIOCARBON, Vol 43, Nr 2B, 2001, p 679-689

Proceedings of the 17 th International ${ }^{14} \mathrm{C}$ Conference, edited by I Carmi and E Boaretto 
ples of atmospheric $\mathrm{CO}_{2}$ from Gliwice, the west boundary city, were taken for determination quality of the Suess effect. They do not reveal ${ }^{14} \mathrm{C}$ concentration in the central part of Upper Silesia, but show it on the western boundary. It is believed that this effect is stronger in the central part than on the western boundary of the investigated region. Earlier investigations of changes of ${ }^{14} \mathrm{C}$ concentration within the GOP boundary were carried out by Awsiuk and Pazdur (1986) and aimed at determining the extent of the Suess effect.

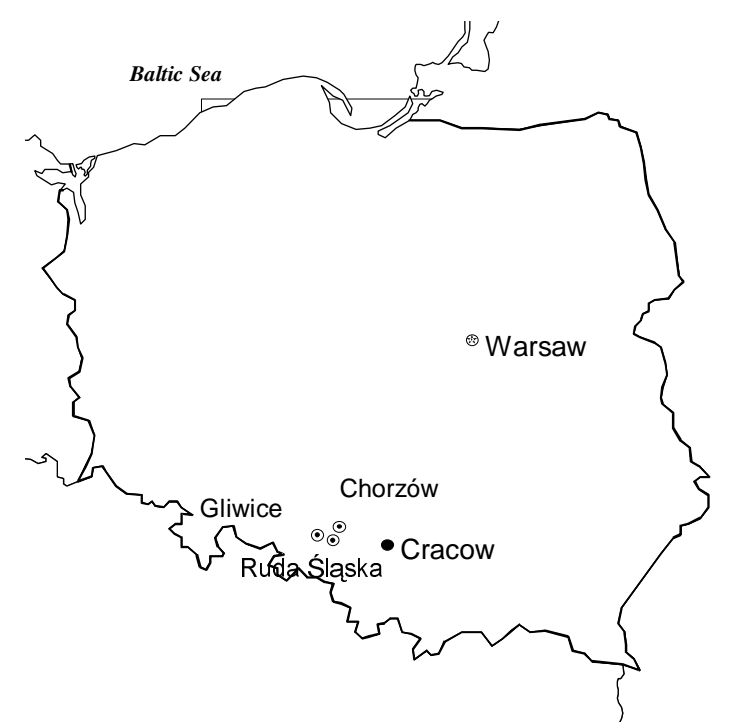

Figure 1 Map of Poland with locations of sample collection sites

\section{SAMPLES}

Samples from tree rings were used for interannual and seasonal measurements of ${ }^{14} \mathrm{C}$ concentrationchanges. Samples of the atmospheric $\mathrm{CO}_{2}$ were also examined. On the basis of tree ring samples annual changes of ${ }^{14} \mathrm{C}$ concentration in the period $1965-1995$ were determined, while samples of the atmospheric $\mathrm{CO}_{2}$, collected weekly, allowed to evaluate ${ }^{14} \mathrm{C}$ concentration changes within one year.

Tree trunks for the experiments were collected from forests in city surroundings. Annual pine tree rings (Pinus sylvestris) — the most abundant tree in Polish forests—constituted the material for isotopic analysis. The choice of tree species was imposed by the necessity to unify experimental material as well as by the fact that researchers world-wide commonly use these trees. An important argument in favor of pine utilization for ${ }^{14} \mathrm{C}$ measurements is the fact that pine, as a coniferous tree, has significantly longer vegetation period than a deciduous tree. This allows tracking ${ }^{14} \mathrm{C}$ concentrationchanges over a longer period. In order to compare ${ }^{14} \mathrm{C}$ concentration changes in tree rings of deciduous and coniferous trees, concentration of this isotope in tree rings of poplar (Populus nigra) was determined.

Sample preparation for ${ }^{14} \mathrm{C}$ measurements involved separation of subsequent tree rings from the trunk cross-section along the boundaries of the rings. This mechanical operation is made by cutting the material with chisel. The amount of the material needed for analysis depends on the ${ }^{14} \mathrm{C}$ measurement technique and, in our case, it was several grams of wood per sample. The sample material for ${ }^{13} \mathrm{C}$ content analysis was collected in Chorzów. 
Atmospheric $\mathrm{CO}_{2}$ samples were collected weekly using the static method described by Nydal and Lövseth (1983). This method is based on absorption of $\mathrm{CO}_{2}$ from the atmosphere in a $2 \%$ solution of $\mathrm{NaOH}$. This absorbing solution was poured to a $0.5 \mathrm{~m}^{2}$ cuvette in a place chosen to assure free exchange of the air over the cuvette. The place was situated far from chimneys and sources of emission that could decrease the ${ }^{14} \mathrm{C}$ concentration in the atmosphere. In this method significant fractionation of carbon isotope was observed (Usdowski and Hoefs 1986). This effect was taken into account by using measurements of $\delta^{13} \mathrm{C}$ in subsequent samples, which were then used for correction of $\Delta^{14} \mathrm{C}$.

For ${ }^{14} \mathrm{C}$ measurements, LSC and GPC were used according to the procedure described by Pazdur and Pazdur (1986), and Pawlyta et al. (1998).

\section{RESULTS}

Figure 2a presents annual changes of $\Delta^{14} \mathrm{C}$ in tree rings from Ruda Sląska and Chorzów, and changes of ${ }^{14} \mathrm{C}$ concentration in the "clean air". Data on the concentration in the "clean air" were taken from the work by Levin and Kromer (1997) and constitute a record of changes of ${ }^{14} \mathrm{C}$ concentration in the atmospheric $\mathrm{CO}_{2}$ from Schauinsland $\left(48^{\circ} \mathrm{N}, 8^{\circ} \mathrm{E}, 1205 \mathrm{~m}\right.$ asl, Black Forest, Southern Germany). For this calculation average value of $\Delta^{14} \mathrm{C}$ determined between May and August for Schauinsland were used. These changes can be described by the expression $\Delta \Delta^{14} \mathrm{C}=417 \exp (-0.0625$ - t) (\%o), where $t$ is time counted since 1974 .

It can be assumed that relations describing changes of this value for data from Chorzów and Ruda Śląska are of similar character. The equations take the form $\mathrm{D}^{14} \mathrm{C}=\mathrm{Aexp}(-\mathrm{B} \cdot \mathrm{t})$ : for Ruda Śląska (Pinus sylvestris), parameter $\mathrm{A}=(680 \pm 40) \%$, and $\mathrm{B}=(6.77 \pm 0.50) \cdot 10^{-2} 1 / \mathrm{yr}$, and for Chorzów (Populus nigra) $\mathrm{A}=(675 \pm 70) \%$, and $\mathrm{B}=(5.91 \pm 0.45) \cdot 10^{-2} 1 / \mathrm{yr}$, where $t$ is time counted since 1965.

Table 2 Results of $\Delta^{14} \mathrm{C}$ and ${ }^{14} \mathrm{~S}$ measurements in tree rings (Pinus silvestrs) from Ruda Śląska. $\Delta^{14} \mathrm{C}$ values were corrected using $\delta^{13} \mathrm{C}=-25 \%$.

\begin{tabular}{lccc}
\hline & \multicolumn{3}{c}{$\Delta^{14} \mathrm{C}$} \\
Location & Year & $(\%)$ & ${ }^{14} \mathrm{~S}(\%)$ \\
\hline Ruda Śląska & 1965 & $724.6 \pm 13.0$ & $-0.42 \pm 0.20$ \\
& 1967 & $502.9 \pm 13.0$ & $-8.7 \pm 0.2$ \\
1969 & $526.8 \pm 11.3$ & $-2.7 \pm 0.3$ \\
1971 & $493.7 \pm 9.4$ & $-0.62 \pm 0.15$ \\
1973 & $377.7 \pm 8.2$ & $-4.5 \pm 0.3$ \\
1975 & $323.5 \pm 11.3$ & $-4.9 \pm 0.3$ \\
1977 & $271.8 \pm 10.6$ & $-5.5 \pm 0.3$ \\
1979 & $273.2 \pm 11.2$ & $-2.4 \pm 0.4$ \\
1981 & $229.2 \pm 10.4$ & $-3.2 \pm 0.4$ \\
1983 & $141.5 \pm 8.6$ & $-7.8 \pm 0.4$ \\
1985 & $106.8 \pm 8.4$ & $-8.5 \pm 0.4$ \\
1987 & $92.4 \pm 7.6$ & $-7.8 \pm 0.4$ \\
1989 & $161.8 \pm 10.2$ & $-0.12 \pm 0.2$ \\
1991 & $120.7 \pm 8.4$ & $-2.04 \pm 0.2$ \\
1993 & $89.5 \pm 7.5$ & $-3.3 \pm 0.4$ \\
1995 & $128.4 \pm 7.5$ & $1.4 \pm 0.4$ \\
\hline
\end{tabular}


A local Suess effect can be described by the following value (Florkowski and Kuc 1979):

$$
{ }^{14} \mathrm{~S}=\frac{\Delta^{14} \mathrm{C}-\Delta^{14} \mathrm{C}_{\text {backgr }}}{1000+\Delta \Delta^{14} \mathrm{C}_{\text {backgr }}} \cdot 100 \%,
$$

where $\Delta{ }^{14} \mathrm{C}$ and $\Delta{ }^{14} \mathrm{C}_{\text {backgr }}$ mean ${ }^{14} \mathrm{C}$ concentrations in the sample examined and in the "clean air". Annual changes of ${ }^{14} \mathrm{~S}$ determined on the basis of measurements for samples from Chorzów and Ruda Śląska are presented in Figures $2 \mathrm{~b}$ and listed in Table 1 (see Appendix) and Table 2. The values of ${ }^{14} \mathrm{~S}$ determined for Ruda Ślaska are much lower than the corresponding values determined for Chorzów for the same year. The discrepancies are the results of differences in species of the trees examined. Annual tree rings of pine were used as samples from Ruda Ślaska because the vegetative period in our climatic zone is much longer than that for deciduous trees. To determine changes of carbon isotopic composition for Chorzów annual tree rings of poplar, a deciduous tree, were used. Unlike deciduous trees, coniferous trees begin the assimilation cycle earlier, which allows to register the decrease of ${ }^{14} \mathrm{C}$ concentration due to seasonal changes of $\mathrm{CO}_{2}$ emission caused by fossil fuel combustion.

The lowest values of ${ }^{14} \mathrm{~S}$ were registered for Ruda Ślaska in $1983-1987$ and the minimal value for that time span was $-8.7 \%$. Minimal value of ${ }^{14} \mathrm{~S}$ for Chorzów was registered in 1968 and was $-7.45 \%$. The values of ${ }^{14} \mathrm{~S}$ for Chorzów in $1971,4.17 \%$, and $1989,6.02 \%$, are not presented in the figure. Such values indicate that concentration of ${ }^{14} \mathrm{C}$ isotope in those years was larger than the concentration in Schauinsland and are contrary to the assumption about ${ }^{14} \mathrm{C}$ concentration in the "clean air". Average values of the Suess effect described by ${ }^{14} \mathrm{~S}$ are $-4.05 \pm 1.3 \%$ in $1965-1995$ for Ruda Śląska and $-1.4 \pm$ 0.9\% in 1966-1992 for Chorzów.

The values of ${ }^{14} \mathrm{~S}$ in the atmospheric $\mathrm{CO}_{2}$ from Gliwice are illustrated in Figure 3 and listed in Table 3 (see Appendix). The maximum value was registered from 18 to 25 July 1995 and is $9.29 \%$, while the minimal value was registered from 10 to 17 December 1994 and is $-7.25 \%$. The maximum and minimum values of ${ }^{14} \mathrm{C}$ correspond to maximum and minimum values of $\Delta{ }^{14} \mathrm{C}$ in the atmospheric $\mathrm{CO}_{2}$ in the examined period (see Table 3 ).

\section{CALCULATED CHANGES OF FOSSIL $\mathrm{CO}_{2}$ CONCENTRATION IN THE ATMOSPHERE}

The value of $\mathrm{CO}_{2}$ concentration in the atmosphere is a sum of two components: natural $\mathrm{CO}_{2}$ concentration changes in the atmosphere and changes due to the global Suess effect, which are described by $\mathrm{C}_{\text {backgr }}$ referred to as the natural component (background concentration). Concentration changes due to a local Suess effect are expressed by $\mathrm{C}_{\text {fossil }}$ referred to as the emission component (fossil fuel concentration, Levin et al. 1989). In order to determine the emission component the following formula is used:

$$
\mathrm{C}_{\text {fossil }}=\mathrm{C}_{\text {backgr }} \cdot\left[\frac{{ }^{14} \mathrm{C}_{\text {backgr }}-{ }^{14} \mathrm{C}}{{ }^{14} \mathrm{C}_{\text {backgr }}} \cdot 100 \%\right]
$$

where $\mathrm{C}_{\text {backgr }}$ stands for $\mathrm{CO}_{2}$ concentration in the "clean air", in (ppmv), ${ }^{14} \mathrm{C}_{\text {backgr }}$ and ${ }^{14} \mathrm{C}$-in a "clean air" and for examined region, in (pMC). 
a)

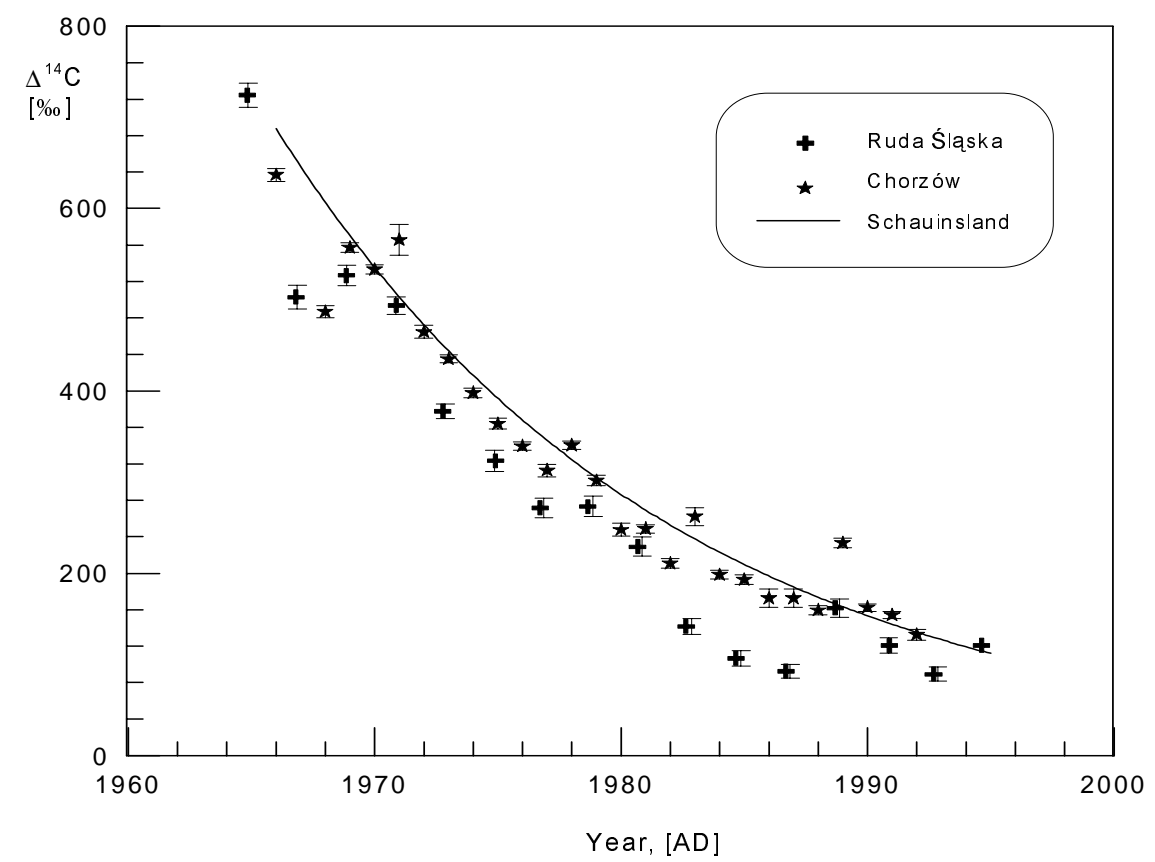

b)

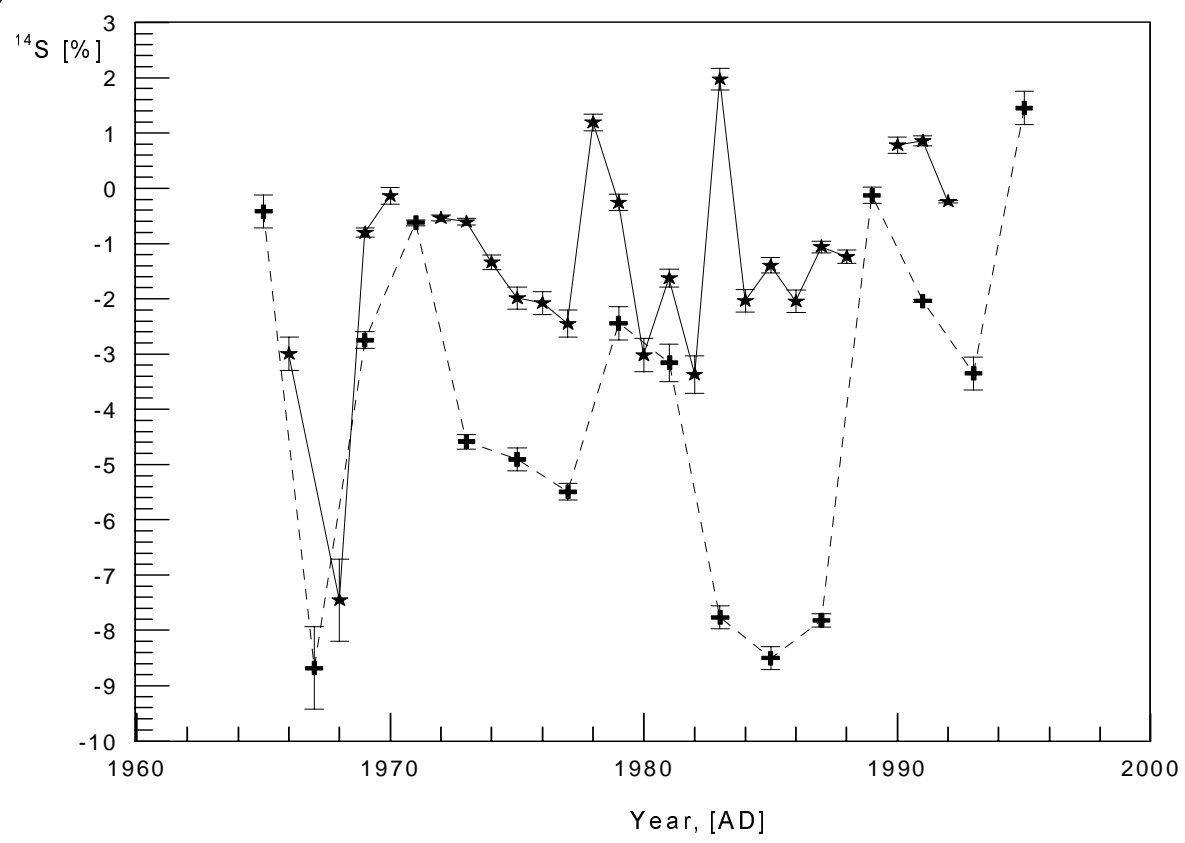

Figure 2 Changes of ${ }^{14} \mathrm{C}$ (part a) and ${ }^{14} \mathrm{~S}$ (part b) in tree rings from Upper Silesia: Ruda Śląska (Pinus silvestris) and Chorzów (Populus nigra). Solid line shows results for "clean air" according to Levin and Kromer (1997) 


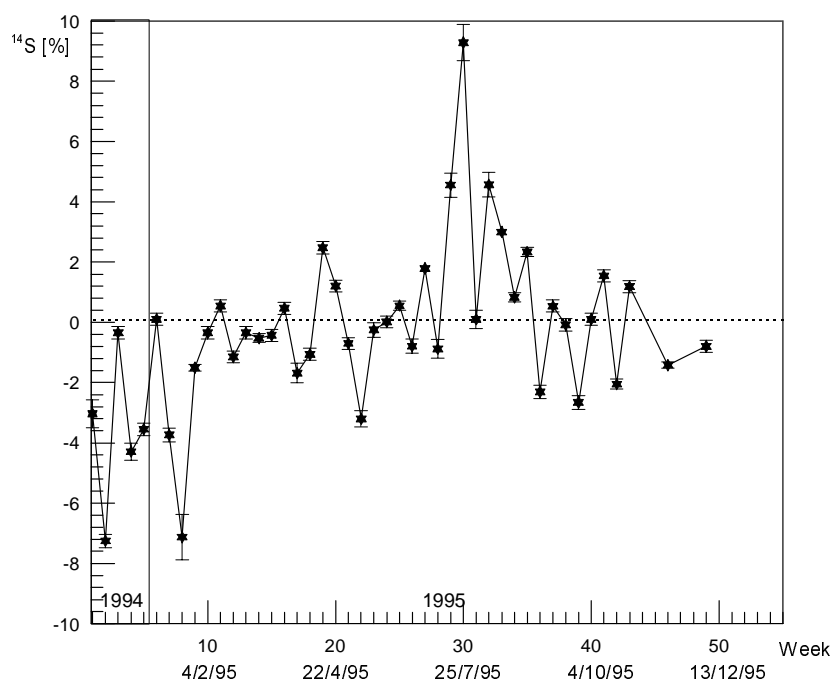

Figure 3 Changes of ${ }^{14} \mathrm{~S}$ in atmospheric $\mathrm{CO}_{2}$ in Gliwice. Samples were collected between December 3, 1994 and December 5, 1995. Solid line represents course of current mean value from three subsequent ${ }^{14} \mathrm{~S}$ values

Research carried out in the University of Heildelberg was performed to determine influence of the emission component on $\mathrm{CO}_{2}$ concentration in the region of German research stations like Schauinsland, Westerland, and Heidelberg in 1982-1988 (Levin et al. 1989). Values of $\mathrm{C}_{\text {backgr }}$ and ${ }^{14} \mathrm{C}_{\text {backgr }}$ were taken from measurements in Jungfraujoch $\left(28^{\circ} \mathrm{N}, 16^{\circ} \mathrm{E}, 2376 \mathrm{~m}\right.$ asl, Swiss Alps). Relatively large seasonal changes of the emission component in the considered period were observed for the station in Heidelberg. The maximum value (17 ppmv) of this component was for January, but the minimum value (2 ppmv) was for July. Influence of the emission component on $\mathrm{CO}_{2}$ concentration in Schauinsland and Westerland is significantly poorer and the maximum values during the year are 4 ppmv and 6 ppmv, respectively. In the research carried out by the authors of this work the relation expressed by equation (2) was used. Values of $\mathrm{CO}_{2}$ concentration and ${ }^{14} \mathrm{C}$ concentration in the "clean air" were taken from measurements done in Schauinsland (Levin et al. 1995; Levin and Kromer 1997). The results of calculations are represented in Figures 4a and 4b. For comparison, beside determined values of the emission components for Chorzów and Ruda Śląska, the values of $\mathrm{C}_{\text {fossil }}$ for Cracow were also presented in Figure 5. The values for Cracow were determined basing on the average value of $\Delta^{14} \mathrm{C}$ for the period from May to August in 1983-1994 (Kuc and Zimnoch 1998).

The determined values of the emission component for Gliwice are presented in Figure $4 \mathrm{~b}$. Negative values of $\mathrm{C}_{\text {fossil }}$ appearing in summer time are a consequence of increase of ${ }^{14} \mathrm{C}$ concentration over values observed in the "clean air". Values of ${ }^{14} \mathrm{C}$ concentration in "clean air" were determined basing of $\Delta^{14} \mathrm{C}$ for Schauinsland station and adding to this value a correction of $+6.0 \%$. This is the average value of underestimation of ${ }^{14} \mathrm{C}$ concentration in that station with respect to Jungfraujoch (Levin et al. 1995; Kuc and Zimnoch 1998). The amplitude of seasonal changes of ${ }^{14} \mathrm{C}$ concentration in ecologically clean regions is substantially lower then the amplitude observed in regions where the anthropogenic effects are present. Analyzing changes of $\Delta^{14} \mathrm{C}$ for Cracow (see Figure 5) on the basis of the data given by Kuc and Zimnoch (1998), the presence of periods for which ${ }^{14} \mathrm{C}$ concentration is higher than ${ }^{14} \mathrm{C}$ concentration in the "clean air" are observed. This effect has not been explained, yet. It is believed that this effect is connected with discrimination of ${ }^{12} \mathrm{C}$ isotope in the assimilation process of $\mathrm{CO}_{2}$ by plants. Investigations and calculations performed in Cracow refer to ${ }^{14} \mathrm{C}$ concen- 


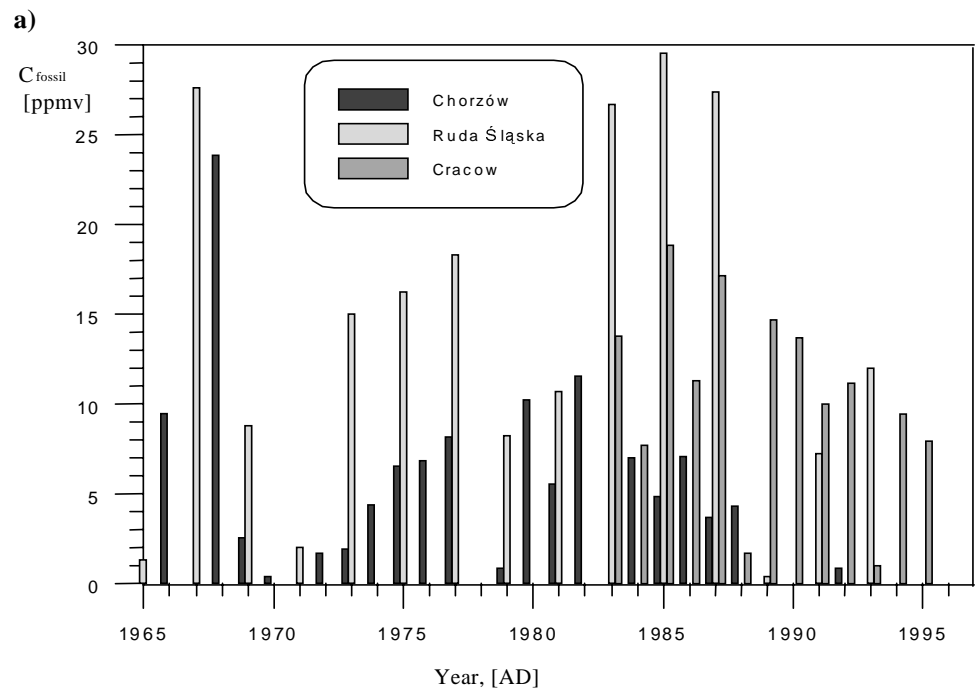

b)

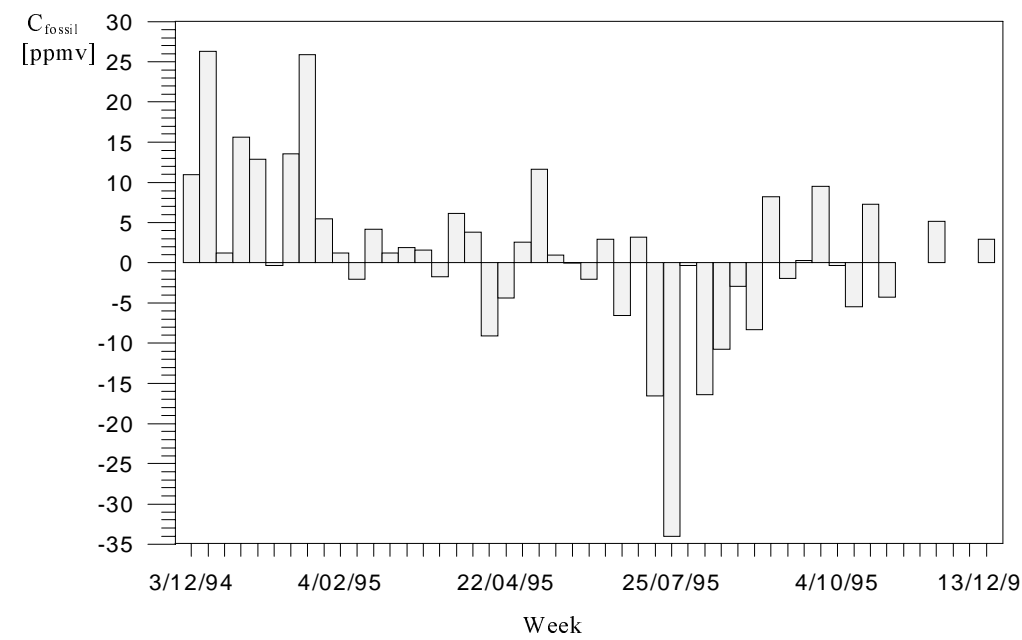

Figure 4 a) Changes of component value $\mathrm{C}_{\text {fossil }}$ for Ruda Śląska, Chorzów, and Cracow. Values of emission component for Cracow were determined on the basis of ${ }^{14} \mathrm{C}$ mean value for period of May-August (Kuc and Zimnoch 1998), b) Changes of $C_{\text {fosil }}$ values evaluated for Gliwice in the period between December 3, 1994 and December 5, 1995.

tration Schauinsland, similarly as in this work. In both cases the correction procedure, required to take into account differences of ${ }^{14} \mathrm{C}$ concentrations between Jungfraujoch and Schauinsland, was used (Levin et al. 1989).

\section{SUMMARY}

The authors present preliminary results obtained as part of a project investigating ${ }^{14} \mathrm{C}$ and ${ }^{13} \mathrm{C}$ concentration changes during the last 150 years in Poland, including both clean and industrial regions. These preliminary results describe the Suess effect recorded in industrial Upper Silesia region. The results were obtained from ${ }^{14} \mathrm{C}$ concentration measurements in annual tree rings (Pinus silvestris 
and Populus nigra) from the central part of that region. They constituted the base for determining ${ }^{14} \mathrm{C}$ and $\mathrm{C}_{\text {fossil }}$. Corrected values of carbon concentration in Schauinsland were also useful for these calculations. Differences in ${ }^{14} \mathrm{C}$ concentration depend on tree species and their vegetation periods. In the future we will use one species (Pinus silvestris) for investigations. To determine seasonal change qualities of ${ }^{14} \mathrm{C}$ concentration measurements in atmospheric $\mathrm{CO}_{2}$ in Gliwice were performed. Significantly lower ${ }^{14} \mathrm{C}$ concentration was noted in the winter season, but results did not answer the question how large the decrease of concentration in the center of this area was.

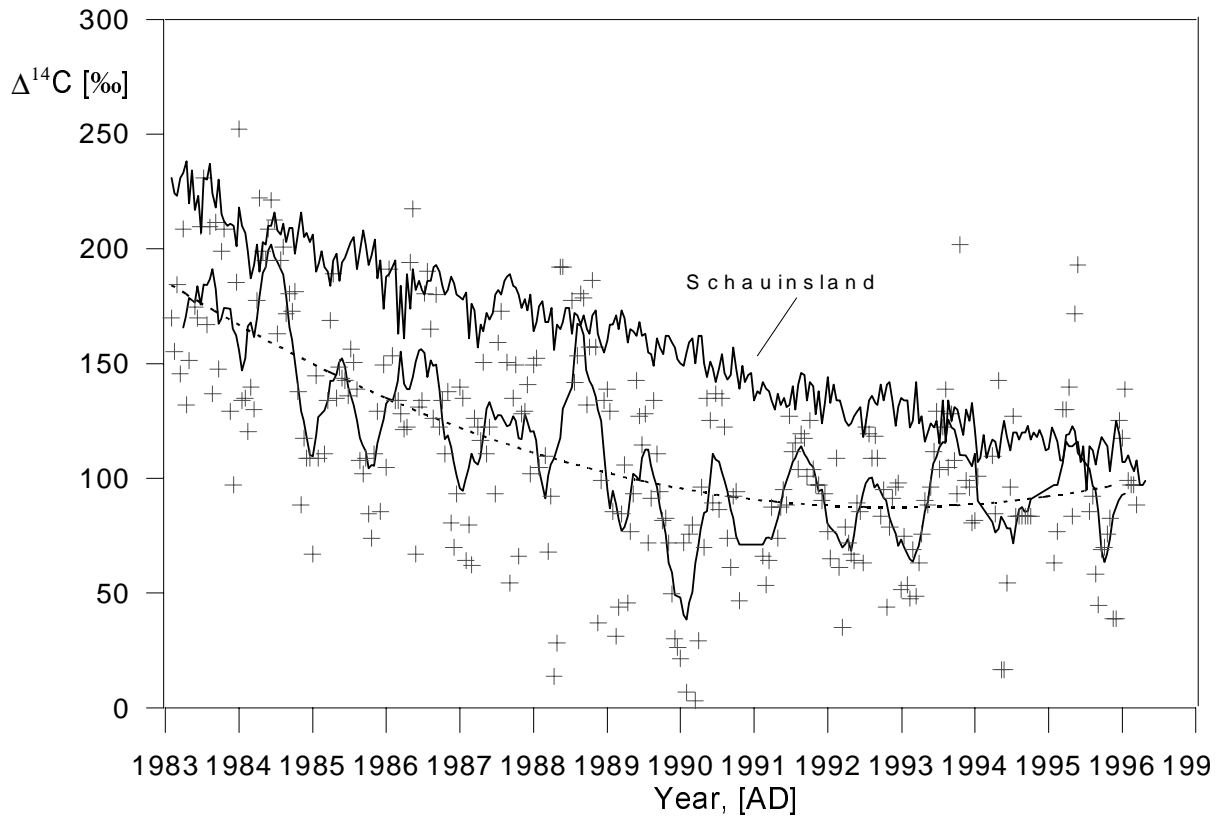

Figure 5 Comparison of ${ }^{14} \mathrm{C}$ in atmospheric $\mathrm{CO}_{2}$ for Cracow (Kuc and Zimnoch 1998) and Schauinsland (Levin and Kromer 1997)

\section{ACKNOWLEDGMENTS}

The research presented was supported by the State Committee for Scientific Research (KBN) under the grant No. 6P04G07410 and Silesian University of Technology under the grant BW 456/RMF-1/ 2000 .

\section{REFERENCES}

Awsiuk R, Pazdur MF. 1986. Regional Suess effect in Upper Silesia urban area. Radiocarbon 28(2A):65560.

Florkowski T, Kuc T. 1979. Carbon isotopes and sulphur content as indicators of atmospheric pollution from burning fossil fuels. Environment International 2: 431-5.

Kuc T, Zimnoch M. 1998. Changes of the $\mathrm{CO}_{2}$ sources and sinks in polluted urban area (Southern Poland) over last decades, derived from the carbon isotope composition. Radiocarbon 40(1):417-23.

Levin I, Suchard J, Kromer B, Munnich KO. 1989. The continental European Suess effect. Radiocarbon 31(3):431-40.

Levin I, Graul R, Trivett NBA. 1995. Long-term observation of atmospheric $\mathrm{CO}_{2}$ and carbon isotopes at continental sites in Germany. Tellus 47B:23-34.

Levin I, Kromer B. 1997. Twenty years of high-precision atmospheric ${ }^{14} \mathrm{CO}_{2}$ observations at Schauinsland station, Germany. Radiocarbon 39(2):205-18.

Nydal R, Lövseth K. 1983. Tracing bomb ${ }^{14} \mathrm{C}$ in the atmosphere, 1963-1980. Journal of Geophysical Research 88:3621-42.

Oeschger H, Siegenthaler U, Gugelmann A. 1975. A box 
diffusion model to study the carbon dioxide exchange in nature. Tellus 27:168-92.

Pawlyta J, Rakowski AZ, Pazdur A, Miller BF, Harknes DD, 1998. Commissioning of a Quantulus 1220 liquid scintillation beta spectrometer for the measurement of C-14 and $\mathrm{H}-3$ at natural abundance level.Radiocarbon 40(1):201-8.

Pazdur A, Pazdur M F. 1986. Aparatura pomiarowa Labratorium ${ }^{14} \mathrm{C}$ w Gliwicach. Doswiadczenia konstrukcyjne i eksploatacyjne (The measuring equipment of the Gliwice Radiocarbon Laboratory. Experience gathered in the construction and exploitation). Zeszyty Naukowe Politechniki Slaskiej, Seria MatematykaFizyka. Zeszyt 46-Geochronometria 1:55-69.

Siegenthaler U, Oeschger H. 1987. Biospheric $\mathrm{CO}_{2}$ emission during the past 200 years reconstructed by deconvolution of ice core data. Tellus 39:140-54.

Suess HE. 1955. Radiocarbon concentration in modern wood. Science 122:415-17.

Usdowski, E., Hoefs, J. 1986. ${ }^{13} \mathrm{C} /{ }^{12} \mathrm{C}$ partitioning and kinetics of $\mathrm{CO}_{2}$ absorption by hydroxide buffer solutions. Earth and Planetary Science Letters 80:130-4. 


\section{APPENDIX}

Table 1 Results of $\Delta{ }^{14} \mathrm{C}$ and ${ }^{14} \mathrm{~S}$ measurements in tree rings (Populus nigra) from Chorzów

\begin{tabular}{|c|c|c|c|c|}
\hline Location & Year & $\delta^{13} \mathrm{C}(\%)$ & $\Delta^{14} \mathrm{C}(\%)$ & ${ }^{14} \mathrm{~S}(\%)$ \\
\hline \multirow[t]{27}{*}{ Chorzów } & 1966 & -25.7 & $637.2 \pm 7.1$ & $-2.99 \pm 0.30$ \\
\hline & 1967 & -25.9 & - & - \\
\hline & 1968 & -26.8 & $487.0 \pm 7.2$ & $-7.45 \pm 0.45$ \\
\hline & 1969 & -25.9 & $554.6 \pm 4.9$ & $-0.80 \pm 0.15$ \\
\hline & 1970 & -24.5 & $534.9 \pm 5.1$ & $-0.14 \pm 0.10$ \\
\hline & 1971 & -25.3 & $564.8 \pm 11.2$ & $4.17 \pm 0.45$ \\
\hline & 1972 & -25.9 & $462.0 \pm 7.1$ & $-0.54 \pm 0.15$ \\
\hline & 1973 & -25.4 & $434.9 \pm 4.7$ & $-0.61 \pm 0.10$ \\
\hline & 1974 & -26.1 & $398.6 \pm 5.1$ & $-1.34 \pm 0.20$ \\
\hline & 1975 & -25.7 & $364.1 \pm 6.0$ & $-1.99 \pm 0.30$ \\
\hline & 1976 & -25.7 & $339.6 \pm 4.6$ & $-2.08 \pm 0.30$ \\
\hline & 1977 & -25.4 & $312.7 \pm 7.0$ & $-2.45 \pm 0.40$ \\
\hline & 1978 & -25.4 & $340.6 \pm 4.4$ & $1.20 \pm 0.40$ \\
\hline & 1979 & -25.4 & $301.7 \pm 6.0$ & $-0.26 \pm 0.35$ \\
\hline & 1980 & -26.4 & $247.8 \pm 7.0$ & $-3.02 \pm 0.40$ \\
\hline & 1981 & -26.8 & $248.6 \pm 4.8$ & $-1.63 \pm 0.35$ \\
\hline & 1982 & -25.5 & $210.7 \pm 5.2$ & $-3.37 \pm 0.30$ \\
\hline & 1983 & -27.2 & $262.0 \pm 10.0$ & $1.97 \pm 0.20$ \\
\hline & 1984 & -27.1 & $198.3 \pm 4.8$ & $-2.04 \pm 0.30$ \\
\hline & 1985 & -27.1 & $192.8 \pm 5.4$ & $-1.40 \pm 0.25$ \\
\hline & 1986 & - & $172.5 \pm 10.0$ & $-2.04 \pm 0.30$ \\
\hline & 1987 & - & $172.5 \pm 10.0$ & $-1.06 \pm 0.20$ \\
\hline & 1988 & - & $159.3 \pm 4.8$ & $-1.24 \pm 0.20$ \\
\hline & 1989 & -26.0 & $233.3 \pm 5.4$ & $6.02 \pm 0.45$ \\
\hline & 1990 & -26.0 & $162.4 \pm 4.1$ & $0.78 \pm 0.15$ \\
\hline & 1991 & -27.2 & $153.9 \pm 4.2$ & $0.86 \pm 0.15$ \\
\hline & 1992 & -27.2 & $127.7 \pm 6.2$ & $-0.24 \pm 0.10$ \\
\hline
\end{tabular}


Table 3 Results of $\Delta^{14} \mathrm{C}$ and ${ }^{14} \mathrm{~S}$ measurements in atmospheric carbon dioxide from Gliwice.

\begin{tabular}{|c|c|c|c|c|}
\hline Location & Year & $\delta^{13} \mathrm{C}(\% o)$ & $\Delta^{14} \mathrm{C}(\%)$ & ${ }^{14} \mathrm{~S}(\%)$ \\
\hline \multirow[t]{49}{*}{ Gliwice } & $3 / 12 / 94$ & -24.2 & $74.4 \pm 2.3$ & $-3.03 \pm 0.95$ \\
\hline & $10 / 12 / 94$ & -25.6 & $27.6 \pm 3.2$ & $-7.25 \pm 0.25$ \\
\hline & $17 / 12 / 94$ & -28.7 & $104.2 \pm 2.6$ & $-0.34 \pm 0.45$ \\
\hline & $24 / 12 / 94$ & -27.1 & $60.5 \pm 2.7$ & $-4.29 \pm 0.45$ \\
\hline & $31 / 12 / 94$ & -28.1 & $76.4 \pm 2.4$ & $-3.55 \pm 0.45$ \\
\hline & $7 / 01 / 95$ & -22.4 & $117.2 \pm 2.3$ & $0.10 \pm 0.95$ \\
\hline & $14 / 01 / 95$ & -27.2 & $72.4 \pm 1.6$ & $-3.73 \pm 0.45$ \\
\hline & $21 / 01 / 95$ & -28.3 & $34.6 \pm 2.1$ & $-7.13 \pm 0.90$ \\
\hline & $28 / 01 / 95$ & -27.7 & $97.3 \pm 2.6$ & $-1.50 \pm 0.45$ \\
\hline & $4 / 02 / 95$ & -27.4 & $110.2 \pm 2.5$ & $-0.34 \pm 0.40$ \\
\hline & $11 / 02 / 95$ & -25.8 & $121.1 \pm 2.5$ & $0.55 \pm 0.40$ \\
\hline & $18 / 02 / 95$ & -26.7 & $102.2 \pm 2.6$ & $-1.14 \pm 0.45$ \\
\hline & $25 / 02 / 95$ & -25.3 & $112.2 \pm 2.6$ & $-0.34 \pm 0.45$ \\
\hline & $4 / 03 / 95$ & -26.2 & $110.2 \pm 2.5$ & $-0.52 \pm 1.10$ \\
\hline & $11 / 03 / 95$ & -25.0 & $102.2 \pm 2.8$ & $-0.43 \pm 0.45$ \\
\hline & $25 / 03 / 95$ & -28.6 & $112.2 \pm 2.6$ & $0.47 \pm 0.45$ \\
\hline & $1 / 04 / 95$ & -27.6 & $95.3 \pm 3.1$ & $-1.68 \pm 1.20$ \\
\hline & 9/04/95 & -27.5 & $102.2 \pm 2.4$ & $-1.06 \pm 0.45$ \\
\hline & $17 / 04 / 95$ & -25.0 & $122.1 \pm 2.3$ & $2.48 \pm 0.95$ \\
\hline & $22 / 04 / 95$ & -26.6 & $108.2 \pm 2.6$ & $1.21 \pm 0.45$ \\
\hline & $29 / 04 / 95$ & -24.5 & $106.2 \pm 2.5$ & $-0.70 \pm 0.40$ \\
\hline & $6 / 05 / 95$ & -26.6 & $78.4 \pm 2.8$ & $-3.20 \pm 0.60$ \\
\hline & $6 / 06 / 95$ & - & $103.2 \pm 2.7$ & $-0.25 \pm 1.20$ \\
\hline & $13 / 06 / 95$ & -26.8 & $106.2 \pm 2.5$ & $0.02 \pm 0.40$ \\
\hline & $20 / 06 / 95$ & -29.2 & $118.2 \pm 3.6$ & $0.55 \pm 0.45$ \\
\hline & $27 / 06 / 95$ & -26.0 & $103.2 \pm 2.7$ & $-0.79 \pm 1.20$ \\
\hline & 4/07/95 & -27.8 & $138.1 \pm 3.5$ & $1.79 \pm 0.40$ \\
\hline & $11 / 07 / 95$ & -24.7 & $108.2 \pm 3.7$ & $-0.88 \pm 0.50$ \\
\hline & $18 / 07 / 95$ & -21.2 & $166.9 \pm 2.8$ & $4.56 \pm 0.43$ \\
\hline & $25 / 07 / 95$ & -24.8 & $219.6 \pm 2.8$ & $9.29 \pm 0.63$ \\
\hline & $1 / 08 / 95$ & -21.3 & $115.2 \pm 2.6$ & $0.11 \pm 0.45$ \\
\hline & 8/08/95 & -25.3 & $164.9 \pm 2.7$ & $4.57 \pm 0.55$ \\
\hline & $16 / 08 / 95$ & -25.5 & $136.1 \pm 2.6$ & $3.00 \pm 0.45$ \\
\hline & $22 / 08 / 95$ & -25.7 & $112.2 \pm 2.6$ & $0.83 \pm 0.45$ \\
\hline & $29 / 08 / 95$ & -26.0 & $141.0 \pm 2.6$ & $2.34 \pm 0.45$ \\
\hline & $5 / 09 / 95$ & -29.0 & $89.3 \pm 2.9$ & $-2.30 \pm 0.67$ \\
\hline & $12 / 09 / 95$ & -27.1 & $131.1 \pm 2.6$ & $0.54 \pm 0.45$ \\
\hline & $19 / 09 / 95$ & -25.1 & $124.1 \pm 2.6$ & $-0.08 \pm 0.45$ \\
\hline & $29 / 09 / 95$ & -29.2 & $89.3 \pm 2.9$ & $-2.65 \pm 0.67$ \\
\hline & $4 / 10 / 95$ & -26.7 & $120.1 \pm 2.4$ & $0.10 \pm 0.30$ \\
\hline & $11 / 10 / 95$ & -28.1 & $124.1 \pm 2.6$ & $1.55 \pm 0.45$ \\
\hline & $17 / 10 / 95$ & -27.4 & $84.3 \pm 2.6$ & $-2.05 \pm 0.45$ \\
\hline & $24 / 10 / 95$ & -28.9 & $120.1 \pm 2.4$ & $1.19 \pm 0.30$ \\
\hline & $31 / 10 / 95$ & -29.5 & - & - \\
\hline & 7/11/95 & -32.1 & - & - \\
\hline & $15 / 11 / 95$ & -26.2 & $94.3 \pm 2.5$ & $-1.42 \pm 0.40$ \\
\hline & $21 / 11 / 95$ & -27.3 & - & - \\
\hline & $29 / 11 / 95$ & -28.6 & - & - \\
\hline & $5 / 12 / 95$ & -26.1 & $94.3 \pm 2.5$ & $-0.79 \pm 0.38$ \\
\hline
\end{tabular}

